\title{
ANALISIS KEDUDUKAN FUNGSI LEGISLASI ANGGOTA DPRD PEREMPUAN DALAM PENENTUAN KEBIJAKAN PUBLIK
}

\author{
Triana Kurnia Putri, Budiono \\ FKIP Universitas Muhammadiyah Malang, Indonesia \\ Email: kurniatriana23@gmail.com
}

\begin{abstract}
ABSTRAK
Penelitian ini bertujuan untuk mengetahui (1) kedudukan fungsi legislasi anggota perempuan di DPRD Kota Batu Periode 2014-2019 dalam penentuan kebijakan publik; (2) Faktor yang menghambat pelaksanaan fungsi legislasi perempuan di DPRD Kota Batu Periode 2014-2019 dalam penentuan kebijakan publik. Metode penelitian menggunakan deskriptif kualitatif dan menggunakan pendekatan fenomenologi yang dilakukan di DPRD Kota Batu pada bulan April sampai dengan bulan Mei 2019. Subjek penelitian antara lain seluruh anggota legislatif perempuan DPRD Kota Batu periode 2014-2019. Pengumpulan dilakukan melalui observasi langsung, studi dokumentasi/dokumentasi kegiatan serta melakukan wawancara dengan informan. Prosedur analisis data melalui tahapan pengumpulan data, reduksi data, penyajian data dan penarikan kesimpulan atau verifikasi data. Teknik keabsahan data menggunakan prosedur tringangulasi sumber. Hasil penelitian menunjukan: (1) anggota perempuan di DPRD Kota Batu periode 2014-2019 memiliki kedudukan yang sama dengan anggota dewan laki-laki, hal demikian terlihat dalam melaksanakan fungsi legislasi antara perempuan dan laki-laki memiliki keterlibatan yang sama atas kedudukan serta peran yang sama dalam keterlibatan menyuarakan pendapat. (2) Faktor yang menghambat pelaksanaan fungsi legislasi yakni adanya kesalahpahaman antara anggota dewan dengan masyarakat terkait isi dari konten perda, kesalahpahaman antara anggota legislatif dengan anggota eksekutif, kendala waktu, serta kepentingan politik yang sangat menonjol antar anggota dewan.
\end{abstract}

Kata Kunci: Anggota Perempuan; Fungsi Legislasi; Kebijakan Publik; DPRD Kota Batu

\begin{abstract}
This study aims (1) to determine the position of the legislative function of female members in the DPRD Kota Batu for the period 2014-2019 in deciding public policy; (2) Factors were hampering the implementation of the women's legislation function in the DPRD of Batu City in the 2014-2019 period in determining public policy. The research method uses descriptive qualitative and uses a phenomenological approach conducted in the Batu City DPRD from April to May 2019. The research subjects included all-female legislative members of the Batu City DPRD in the 2014-2019 period. The collection is done through direct observation, study documentation /documentation of activities, and conduct interviews with informants. Data analysis procedures through the stages of data collection, data reduction, data presentation, and drawing conclusions or data verification. The data validity technique uses the source triangulation procedure. The results showed: (1) female members in the Batu City DPRD in the 2014-2019 period had the same position as male councilors, this was seen in carrying out the legislative function between women and men having the same involvement in the position and role played by same in involvement in voicing opinions. (2) Factors that hinder the implementation of the legislative function are misunderstandings between members of the council and the community regarding the content of the perda content, misunderstandings between legislative members and executive members, time constraints, and very prominent political interests among members of the council.
\end{abstract}

Keywords: Female members; Legislative Functions; Public Policy; DPRD Kota Batu. 


\section{PENDAHULUAN}

Indonesia adalah negara demokrasi, setiap warga negara memiliki kedudukan yang sama dalam hukum dan pemerintahan, hal yang demikian tercantum pada pasal 27 ayat (1) UUD 1945 berbunyi "segala warga negara bersamaan kedudukannya di dalam hukum dan pemerintahan, dan wajib menjunjung hukum dan pemerintahan itu dengan tidak ada kecualinya". Akan tetapi hal tersebut tidak sepenuhnya dilaksanakan dengan baik dalam hal hak-hak berpolitik, terlebih untuk perempuan. Kesetaraan hak berpolitik antara laki-laki dan perempuan terlihat jelas tidak adanya kesetaraan.

Keberadaan kaum perempuan pada setiap perangkat kerja pemerintahan daerah diharapkan mampu sebagai pelopor dalam perwujudan sistem pemerintahan yang baik (good governance), terutama dalam meningkatkan peran perempuan di bidang pemerintahan dan pembangunan yang selama ini dianggap bukan sebagai persoalan penting. Walaupun peran serta perempuan dalam kancah politik di daerah semakin meningkat, akan tetapi perempuan yang mampu mewakili kaumnya sebagai perumus kebijakan di kelembagaan daerah masih relatif terbatas.

Undang-Undang Nomor 8

Tahun 2012 tentang Pemilihan Umum Anggota Dewan Perwakilan Rakyat, Dewan Perwakilan Daerah, dan Dewan Perwakilan Rakyat Daerah menyertakan sekurang-kurangnya $30 \%$ (tiga puluh persen) keterwakilan perempuan pada kepengurusan partai politik. Hal demikian dimaksudkan untuk memberi kesempatan kepada kaum perempuan dapat bersaing untuk duduk sebagai anggota legislatif. Keterwakilan perempuan diartikan sebagai pemberian kesempatan dan kedudukan yang sama bagi perempuan untuk melaksanakan peranannya dalam bidang eksekutif, legislatif dan yudikatif menuju keadilan dan kesetaraan gender.
Meningkatnya peran perempuan di kelembagaan pemerintahan daerah tidak hanya dalam struktur lembaga eksekutif. Kelembagaan legislatif perempuan telah menunjukkan eksistensinya dengan keberhasilan perempuan untuk duduk sebagai anggota legislatif.

Kedudukan Anggota legislatif diatur dalam Undang-Undang Nomor 23 Tahun 2014 tentang Pemerintahan Daerah pada Pasal 1 Ketentuan Umum menjelaskan bahwa Dewan Perwakilan Rakyat Daerah yang selanjutnya disingkat DPRD adalah lembaga perwakilan rakyat daerah yang berkedudukan sebagai unsur penyelenggara pemerintahan daerah. Kedudukan DPRD disini dapat dimaknai sebagai penyelenggara yang mempunyai fungsi pembentukan Perda, anggaran, dan pengawasan, yang dljalankan dalam kerangka representasi rakyat di daerah.

Menurut Asmawi (2014), kedudukan DPRD sebagai unsur penyelenggara pemerintahan daerah menempatkan DPRD sebagai institusi yang sejajar dengan pemerintah daerah. Dalam kedudukan yang sejajar itu, DPRD bersama-sama dengan Kepala Daerah melaksanakan fungsi-fungsi pemerintahan daerah yang meliputi segala urusan menurut asas otonomi dan tugas pembantuan. Dewan Perwakilan Rakyat Daerah atau yang sering disebut dengan DPRD sesunggunya berkedudukan sebagai mitra kerja yang posisinya sejajar dengan Kepala daerah dalam penyelenggaraan pemerintah daerah (Fitri,2015)

Undang-Undang Nomor 23 Tahun 2014 tentang Pemerintahan Daerah, DPRD Kabupaten/Kota mempunyai fungsi: a. Fungsi Pembuatan Perda: fungsi pembuatan perda diwujudkan dalam membentuk peraturan daerah bersama-sama bupati/ wali kota. b. Fungsi Anggara: fungsi anggaran diwujudkan dalam membahas, memberikan persetujuan dan menetapkan APBD bersama pemerintah daerah. 
c.Fungsi Pengawasan: fungsi pengawasan diwujudkan dalam bentuk pengawasan terhadap pelaksanaan undang-undang, peraturan perundangan yang ditetapkan oleh pemerintah, peraturan daerah, peraturan kepala daerah, keputusan kepala daerah dan kebijakan yang ditetapkan oleh pemerintah daerah, dalam menjalankan fungsi legislasi, setiap anggota dewan memiliki hak tersendiri. Hak-hak tersebut yaitu hak inisiatif dan hak amandemen yang menyatakan bahwa anggota Dewan Perwakilan Rakyat berhak mengajukan usul rancangan undang-undang serta untuk mengubah rancangan undang-undang sebelum ditetapkan menjadi undangundang. Selain fungsi legislasi, badan legislatif juga memiliki fungsi kontrol. Fungsi kontrol ini dilakukan dengan cara mengontrol dan mengawasi badan eksekutif dalam arti menjaga supaya semua tindakan badan eksekutif sesuai dengan kebijakankebijakan yang telah ditetapkan.

Dapat ditarik kesimpulan bahwa anggota legislatif memiliki kedudukan dan fungsi yang sudah diatur dalam UndangUndang Nomor 23 Tahun 2014 yakni kedudukan DPRD sebagai penyelenggara pemerintah daerah yang mempunyai fungsi pembentukan Perda, anggaran, dan pengawasan, yang dijalankan dalam kerangka representasi rakyat di daerah.

Pasal 1 Bab I Ketentuan Umum Undang-Undang Nomor 23 Tahun 2014 tentang Pemerintahan Daerah "Dewan Perwakilan Rakyat Daerah yang selanjutnya disebut DPRD adalah lembaga perwakilan rakyat daerah sebagai unsur penyelenggara pemerintahan daerah". Dewan Perwakilan Rakyat Daerah (DPRD) adalah lembaga legislatif atau pembuat peraturan, peraturan perundang-undangan yang dibuatnya mencerminkan kebijakan-kebijakan itu.

Konteks perumusan kebijakan daerah terutama menyangkut perumusan Peraturan Daerah (Perda), diskriminasi gender sering kali dilakukan oleh para pembuat kebijakan.
Selain keputusan-keputusan dibuat kurang berperspektif gender, keterlibatan perempuan dalam bidang tersebut masih kurang. Keberadaan kaum perempuan yang minoritas pada suatu lembaga pemerintahan sering kali kalah dalam menyalurkan suaranya sebagai perumus kebijakan. Kondisi ini tentunya harus menjadi sebuah dorongan bagi kaum perempuan untuk menempatkan diri dan memiliki peran serta fungsi dalam berbagai bidang kehidupan sebagaimana layaknya laki-laki. Hal ini sangatlah penting mengingat saat ini kaum perempuan hampir atau dapat dikatakan telah memiliki pengetahuan, keterampilan atau kecakapan serta ketegasan yang sama dengan laki-laki.

Berdasarkan observasi awal yang telah dilakukan di DPRD Kota Batu peneliti hendak menganalisis lebih lanjut terkait kedudukan dan fungsi anggota legislatif perempuan di DPRD Kota Batu periode 2014-2019. Peneliti ingin menganalisis penerapan kebijakan publik yang dilakukan oleh anggota legislatif perempuan DPRD Kota Batu periode 2014-2019 serta apa saja faktor-faktor yang mendorong serta menghambat anggota legislatif perempuan dalam menentukan suatu kebijakan. Penelitian program kegiatan ini di lakukan di DPRD Kota Batu sebab memenuhi semua unsur yang dibutuhkan dalam penelitian ini.

Penelitian tentang keterwakilan perempuan di lembaga daerah pernah dilakukan oleh Yulyana (2017) berjudul "Keterlibatan Politik Perempuan dalam Proses Legislasi DPRD Kabupaten Karawang Periode 2009 - 2014”. Dalam penelitian tersebut, peneliti membahas mengenai Dukungan adanya partisipasi perempuan dalam politik secara sah di bentuk dalam UU No 10 tahun 2008 tentang pemilihan umum anggota Dewan Perwakilan Rakyat, Dewan Perwakilan Daerah, dan Dewan Perwakilan Rakyat Daerah DPRD Kabupaten Karawang 
telah menerapkan prinsip penerapan kuota $30 \%$ suara perempuan di parlemen juga mengalami kendala. Keterlibatan politik perempuan dalam DPRD Kabupaten Karawang masih belum maksimal baik dilihat dari segi kuota maupun proses legislasi dan produk hukum yang dihasilkan. Padalah pada hakikatnya keterlibatan politik perempuan bukan hanya harus memenuhi kuota tetapi bagaimana keterwakilan tersebut dapat mengahasilkan suatu kebijakan yang memang berusaha untuk menyuarakan kebutuhan kaum perempuan.

Penelitian yang dilakukan di DPRD Kota Batu ini tidak hanya membahas mengenai keterlibatan politik perempuan dalam proses legislasi DPRD, namun lebih menekankan pembahasan terkait kedudukan dan pelaksanaan fungsi legislasi, serta kendala apa saja yang dialami dalam menjalankan fungsi yang dijalankan olah anggota perempuan dalam penentuan kebijakan publik yang mana dilakukan di DPRD Kota Batu periode 2014-2019.

\section{METODE}

Penelitian ini menggunakaan jenis penelitian kualitatif dan menggunakan pendekatan fenomenologi. Husserl (dalam Moleong, 2017) mengartikan fenomenologi sebagai :1) pengalaman subyektif atau pengalaman fenomenologikal; 2) suatu studi tentang kesadaran dari perspektif pokok dari seseorang. Istilah fenomenologi sering digunakan sebagai anggapan umum untuk menunjukkan pada pengalaman subyektif dari berbagai jenis dan tipe subyek yang ditemui. Dalam arti yang lebih khusus, istilah ini mengacu pada penelitian terdisiplin tentang kesadaran dari perspektif pertama seseorang (Moleong, 2017). Fenomenologi merupakan pandangan berpikir yang menekankan pada fokus kepada pengalaman-pengalaman subyektif manusia dan interpretasiinterpretasi dunia. Dalam hal ini, para fenomenologis ingin memahami bagaimana dunia muncul kepada orang lain (Moleong, 2017). Menurut Kuswarno (2009) pendekatan fenomenologi adalah fakta yang disadari dan masuk ke dalam pemahaman manusia. Fenomenologi merefleksikan pengalaman langsung manusia, sejauh pengalaman itu secara intensif berhubungan dengan suatu objek. Pada dasarnya fenomenologi mempelajari struktur tipe-tipe kesadaran, yang terentang dari persepsi, gagasan, memori, imajinasi, emosi, hasrat, kemauan, sampai tindakan, baik itu tindakan sosial maupun dalam bentuk bahasa. Dapat disimpulkan bahwa penelitianyang dilakukan peneliti menggunakan jenis penelitian kualitatif dengan pendekatan fenomenologi yang memudahkan peneliti menggali fakta dengan cara menganalisis fenomena yang berfokus pada pengalamanpengalaman subyektif manusia dari kegiatan yang terjadi dilapangan.

Berdasarkan judul yang menjadi titik fokus dari permasalahan ini maka lokasi penelitian ini dilaksanakan akan di DPRD Kota Batu. Peneliti memilih lokasi di DPRD Kota Batu dengan berbagai macam pertimbangan yakni melihat kedudukan anggota dewan perempuan yang relatif sedikit untuk berperan langsung terkait fungsi dan keikutsertaan dalam menentukan kebijakan publik yang ada di DPRD Kota Batu, selain itu dikarenakan DPRD Kota Batu merupakan salah satu intansi yang menjembatani aspirasi dari masyarakat Kota Batu.

Moleong (2017) mendeskripsikan subjek penelitian sebagai informan, yang artinya orang pada latar penelitian yang dimanfaatkan untuk memberikan informasi tentang situasi dan kondisi latar penelitian. Subjek penelitian ini merupakan seseorang yang memberikan informasi berkaitan dengan penelitian yang dilakukan oleh peneliti.Dalam penelitian kualitatif, peneliti merupakan subjek utama yang harus ada dalam sebuah penelitian disamping itu subjek penelitian yang dimaksud sdisini 
ialah seluruh anggota legislatif perempuan DPRD Kota Batu Periode 2014-2019.

Teknik pengumpulan data Penelitian ini menggunakan: (1) Observasi, yang merupakan teknik pengumpulan data yang mengharuskan peneliti turun ke lapangan mengamati hal-hal yang berkaitan dengan ruang, tempat, pelaku, kegiatan, benda-benda, waktu, peristiwa, tujuan, dan perasaan. (2) Wawancara, menurut Moleong (2017) wawancara adalah percakapan dengan maksud tertentu. Percakapan dilakukan oleh dua pihak, yaitu pewawancara (interviewer) yang mengajukan pertanyaan dan terwawancara (interview) yang memberikan jawaban atas pertanyaan itu. (3) Dokumentasi, Dokumentasi adalah metode mengkaji dan mengolah data dari dokumendokumen yang sudah ada sebelumnya dan mendukung data penelitian.

Teknik analisis data terdiri dari tahapan pengumpulan data, reduksi data, penyajian data, penarikan kesimpulan. Upaya pengujian kredibilitas data dalam penelitian ini menggunakan prosedur Triangulasi Teknik, menurut Moleong (2017) triangulasi merupakan teknik pemeriksaan keabsahan data yang memanfaatkan sesuatu yang lain. Diluar data itu untuk keperluan pengecekan atau sebagai pembanding terhadap data itu.

\section{HASIL dan PEMBAHASAN}

Kedudukan dan fungsi legislasi anggota perempuan perempuan di DPRD Kota Batu Periode 2014-2019 dalam penentuan kebijakan publik

Kedudukan dapat diatikan sebagai tempat atau posisi seseorang. Kedudukan yang dimaksudkan disini adalah suatu jabatan anggota dewan perempuan di DPRD Kota Batu periode 2014-2019 dalam melaksanakan fungsi legislasi. Empat dari enam anggota dewan perempuan di DPRD Kota Batu Periode 2014-2019 memiliki peranan lebih dalam pelaksanaan fungsi legislasi khususnya dalam pembuatan peraturan daerah, hal ini terbukti dengan adanya keterlibatan anggota dewan perempuan masuk kedalam bagian Badan Pembentukan Peratuan Daerah (BAPEMPERDA) yang merupakan badan yang fungsi dalam pembentukan perda. Kedudukan dewan dalam pelaksanaan fungsi legislasi ini nantinya akan terlihat bagaimana keterlibatan anggota dewan mengemban amanah dari masyarakat, seperti halnya anggota dewan perempuan di DPRD Kota Batu periode 2014-2019, seberapa jauh mereka terlibat dalam pembuatan perda untuk meningkatkan kesejahteraan masyarakat.

Penelitian mengenai keterwakilan perempuan juga pernah dilakukan oleh Artina (2016) pada penelitian tersebut keterwakilan perempuan di lembaga legislatif dinilai penting dalam upaya meningkatkan partisipasi politik perempuan, namun dalam penerapannya banyak tantangan dan kendala yang harus dihadapi perempuan legislatif saat pencalegan. Hal yang demikian juga berdampak pada prosentase jumlah antar anggota laki-laki yang tidak seimbang dengan jumlah perempuan. Pada penelitian tersebut juga menilai bahwa pemilihan anggota legislatif berpengaruh terhadap kebijakan affirmative action keterwakilan perempuan di lembaga legislatif. Penelitian yang sama dilakukan oleh Suciptaningsih (2010) permasalahan perempuan di Kabupaten Kendal sangat kompleks, di antaranya disebabkan oleh kuatnya budaya patriarki di masyarakat yang mempengaruhi seluruh sendi kehidupan dan banyaknya kebijakan publik yang belum berperspektif gender akibat rendahnya partisipasi perempuan dalam politik terutama dalam lembaga legislatif sebagai penentu kebijakan. Rendahnya partisipasi perempuan dalam lembaga legislatif di Kabupaten Kendal dikarenakan banyaknya kendala yang dihadapi perempuan untuk maju ke ranah politik, seperti kendala sosial budaya, politik, psikologi dan ekonomi. 
Dari hasil penelitian yang diperoleh, masing-masing anggota dewan di DPRD Kota Batu periode 2014-2019 memiliki tugas dan wewenang yang sama begitu juga dengan pelaksanaan fungsi legislasi, meskipun beberapa diantaranya memiliki peran lebih yakni tergabung dengan anggota BAPEMPERDA. Hal itu tidak menutup kemungkinan bahwa anggota dewan lain yang tidak tergabung ke dalam badan itu tidak dapat berperan dalam setiap kali pembuatan peraturan daerah. Anggota dewan yang lainnya baik itu anggota dewan perempuan ataupun laki-laki dapat berperan untuk melaksanakan fungsi legislasi hanya saja keberperanan mereka yang berbeda. Dengan terlibatnya anggota dewan DPRD Kota Batu periode 2014-2019 dalam melaksanakan fungsi legislasi yakni dalam pembuatan perda yang merupakan sebuah bentuk dari kebijakan publik maka fungsi legislasi yang sudah dilaksanakan tersebut dapat dikatakan sudah berjalan dengan baik.

Sehubungan dengan kebijakan publik yang dikemukakakn oleh Abdul (2008:23) kebijakan publik adalah suatu tindakan rencana pemerintah untuk mengatur kepentingan umum. Teori tersebut selaras dengan hasil penelitian yang sudah dilakukan, dikatakan menghasilkan suatu kebijakan publik ditandai dengan salah satunya yakni pembuatan perda dan dalam penelitian dapat dilihat bahwa setiap pembuatan sebuah perda di DPRD Kota Batu periode 2014-2019 seluruh anggota dewan terlibat semuanya baik itu laki-laki maupun perempuan yang semuanya terbagi menjadi beberapa pansus. Kedudukan anggota perempuan di DPRD Kota Batu periode 2014-2019 memiliki kedudukan yang sama dengan anggota dewan laki-laki, hal demikian terlihat dalam melaksanakan fungsi legislasi antara perempuan dan lakilaki memiliki keterlibatan yang sama atas kedudukan serta peran yang sama dalam keterlibatan menyuarakan pendapat.
Faktor yang menghambat pelaksanaan fungsi legislasi anggota perempuan dalam penentuan kebijakan publik

Keberhasilan dalam membentuk suatu produk hukum yakni peraturan daerah menunjukkan bahwa anggota dewan telah melaksanakan fungsinya dengan baik yaitu fungsi legislasi. Solihah (2016) menjelaskan bahwa dalam melaksanakan fungsi legislasi terdapat faktor yang mempengaruhi yakni kurangnya kinerja dalam menjalankan fungsi legislasi yang tercermin dalam produk legislasinya, ditengarai oleh beberapa hal, antara lain mekanisme kerja anggota dewan dan peraturan perundang-undangan yang terkait dengan kedudukan dan tugasnya sebagai anggota dewan yang belum dipahami dan dilaksanakan sepenuhnya oleh anggota dewan, yang didalamnya menyangkut implemantasi Tata Tertib Dewan dalam melaksanakan fungsi legislasi. Faktor lainnya adalah aspek SDM anggota Dewan baik tingkat pendidikan, pengalaman mau pun kapabilitasnya dalam menampung dan mengakomodir aspirasi masyarakat dan menindaklanjutinya dalam bentuk usulan inisiatif RUU; serta fasilitas teknis dan administratif yang belum sepenuhnya dimanfaatkandalam menjalankan proses legislasi. Selain itu kerjasama di antara anggota dewan dalam menyusun dan membentuk kebijakan, yang dipengaruhi oleh fungsi representasi cenderung lebih mengedepankan kepentingan partai politik (kelompok kepentingannya) dibandingkan kepentingan masyarakat secara luas juga menyebabkan terjadinya tarik menarik kepentingan dalam proses legislasi.

Sesuai dengan hasil penelitian didapatkan beberapa faktor yang menghambat dalam pelaksanaan fungsi legislasi diantaranya yaitu: Adanya kesalahpahaman antara anggota dewan dengan masyarakat terkait isi dari konten perda. Setiap kali pembuatan perda, antar tokoh masyarakat dengan anggota dewan sering mengalami ketidak pahaman 
dari isi dari perda yang dibentuk. Hal ini dikarenakan sebagian dari tokoh-tokoh masyarakat seringkali menolak adanya pembentukan perda itu yang akhirnya menimbulkan perdebatan, sehingga perda yang akan dibentuk mengalami kemoloran waktu dari estimasi yang ditentukan. mengatasi kendala yang demikian, anggota dewan selalu mempertemukan dengan masyarakat yang kemudian raperda itu dibetulkan sesuai dengan musyawarah antara anggota dewan dengan masyarakat dan dibantu oleh tim pembuat perda yang nantinya diselaraskan serta diuji publik lagi

Kesalahpahaman antara anggota legislatif dengan anggota eksekutif. Selain adanya perbedaan pendapat dengan masyarakat, anggota dewan juga mengaku sering kali berbeda pendapat oleh walikota terkait pembuatan perda. Beberapa kali dalam persetujuan pembuatan perda wali kota menggagalkan raperda yang sudah sebelumnya sudah disusun oleh anggota dewan DPD Kota Batu.

Kendala waktu, Hasil penelitian yang dilaksanakan, anggota dewan juga mengganggap waktu menjadi salah satu faktor penghambat dalam melaksanakan fungsi legislasi. Hal demikian terjadi karena setiap kali pembuatan sebuah perda, DPRD Kota Batu tidak pernah tepat dalam melaksanakan agenda kegiatan yang sudah di jadwalkan. Mekanisme dalam menetapkan agenda kegiatan yang sudah terjadwal tidak jarang tidak bisa terlaksanakan karena kesediaan waktu yang ditetapkan ternyata tidak cukup. Hal demikian berimbas pada pembuatan perda yang seharusnya bisa terselesaikan dengan baik justru terlambat.

Kepentingan politik, Kepentingan politik masing-masing anggota dewan di DPRD Kota Batu periode 2014-20129 dilihat sangat kental. Pembuatan sebuah perda merupakan wujud dari peranan anggota dewan dalam menjalankan fungsi legislasi, namun beberapa anggota dewan terlihat masih mementingkan kepentingan pribadinya bukan untung kepentingan bersama dalam merealisasikan terbentuknya sebuah perda.

Berdasarkan hasil wawancara dari penelitian, faktor-faktor penghambat dalam pembuatan perda yang ada dalam pelaksanaan fungsi legislasi dapat terjadi apabila anggota dewan tidak memerankan perannya sesuai fungsinya karna adanya kehadiran DPRD sendiri adalah orang-orang yang diberikan kepercayaan oleh masyarakat suatu daerah untuk menjadi wakil mereka yang bisa mengaspirasi keinginan masyarakat untuk hidup yang lebih baik lagi (Zinggra, 2017).

Pelaksanaan fungsi legislasi DPRD telah berjalan dengan baik sebagaimana mestinya namun dalam pelaksanaannya masih ditemukan sekurang-kurangnya menjadi catatan penting DPRD Kota Batu dalam memperbaiki kualitas kinerja yang belum maksimal. Faktor seperti seringnya terjadi kesalahpahaman antara anggota dewan dengan masyarakat terkait isi dari konten perda menjadi faktor dalam proses pebahasan dan pengesahan suatu peraturan. Hal tersebut juga menjadi faktor menghambat pelaksanaan fungsi legislasi DPRD Kota Batu periode 2014-2019.

\section{SIMPULAN}

Anggota perempuan di DPRD Kota Batu periode 2014-2019 memiliki kedudukan yang sama dengan anggota dewan laki-laki, hal demikian terlihat dalam melaksanakan fungsi legislasi untuk setiap kali pembuatan perda antara anggota dewan perempuan dan anggota dewan laki-laki tidak ada perbedaan, semua memiliki keterlibatan yang sama atas kedudukan serta peran dalam keterlibatan menyuarakan pendapat meski dari komisi dan badan yang berbeda-beda.

Faktor yang menghambat dalam pelaksanaan fungsi legislasi diantaranya yaitu: a. Adanya kesalah pahaman antara anggota dewan dengan masyarakat terkait 
isi dari konten perda. b. Kesalahpahaman antara anggota legislatif dengan anggota eksekutif. c. Kendala waktu d. Kepentingan politik

\section{DAFTAR PUSTAKA}

Abdul Wahab, Solichin. 2008. Analisis Kebijaksanaan: dari Formulasi ke Implementasi Kebijaksanaan Negara. Jakarta: Sinar Grafika

Artina, Dessy. 2016. Keterwakilan Politik Perempuan dalam Pemilu Legislatif Provinsi Riau Periode 2014-2019. Jurnal Hukum IUS QUIA IUSTUM, 23(1) 123-140

Asmawi. 2014. Dewan Perwakilan Rakyat Daerah Dalam Perundang-Undangan Pemerintahan Daerah dan Lembaga Legislatif Daerah. Jurnal Cita Hukum, 2 (1) 1-18

Yulyana, Eka. 2017. Keterlibatan Politik Perempuan dalam Proses Legislasi DPRD Kabupaten Karawang Periode 2009-2014. Jurnal Politikom Indonesiana, 2 (2) $105-113$

Fitri, Sunanda Haizel. 2015. Kedudukan Dewan Perwakilan Rakyat Daerah (DPRD) Dalam Penyelenggaraan Pemerintahan Daerah Berdasarkan Undang-Undang Nomor 23 Tahun 2014. Jurnal Online Mahasiswa Fakultas Hukum, 2 (1) 1-14

Fitriani, Dian Afifah Neneng Yani Yuningsih.2016. Analisis Kebijakan Pemerintah Tentang Pencegahan Dan Penanganan Korban Perdagangan (Trafficking) Perempuan dan Anak di Kabupaten Cianjur. Jurnal CosmoGov, 2 (2) 330-356

Kuswarno, Engkus. 2009. Metodologi Penelitian Komunikasi Fenomenologi. Bandung:Widya Padjajaran.

Moleong, Lexy J. 2017. Metodologi Penelitian Kualitatif. PT Remaja Rosdakarya, Bandung.
Ramdhani, Abdullah dan Muhammad Ali Ramdhani. 2017. Konsep Umum Pelaksanaan Kebijakan Publik. Jurnal Publik, 11 (1) 1-12

Suciptaningsih, Oktaviani Adhi. 2010. Partisipasi Perempuan Dalam Lembaga Legislatif di Kabupaten Kendal. Jurnal Komunitas, 2 (2) 66-73

Solihah, Ratnia dan Siti Witianti Yani Yuningsih. 2016. Pelaksanaan Fungsi Legislasi Dewan Perwakilan Rakyat Pasca Pemilu 2014: Permasalahan dan Upaya Mengatasinya. Jurnal Ilmu Pemerintahan, 2 (2) 291-307

Undang-Undang Dasar 1945

Undang-Undang Nomor 32 Tahun 2014 tentang Pemerintahan Daerah

Zinggra, Heraldo. 2017. Pelaksanaan Fungsi Dewan Perwakilan Rakyat Daerah (DPRD) Kabupaten Dairi Periode 2014-2019 Dalam Bidang Legislasi. Jom Fisip, 4 (2) 1-14 